\title{
Honey bees performing varroa sensitive hygiene remove the most mite-compromised bees from highly infested patches of brood
}

\author{
Seo Hyun $\mathrm{KIM}^{1}$, Fanny MONDET ${ }^{1,2}$, Maxime HERVÉ ${ }^{3}$, Alison MERCER ${ }^{1}$ \\ ${ }^{1}$ Department of Zoology, University of Otago, Dunedin 9054, New Zealand \\ ${ }^{2}$ INRA, UR 406 Abeilles et Environnement, 84914, Avignon, France \\ ${ }^{3}$ IGEPP, Agrocampus Ouest, INRA, Université de Rennes 1, Université Bretagne-Loire, 35000, Rennes, France
}

Received 19 July 2017 - Revised 4 October 2017 - Accepted 7 December 2017

\begin{abstract}
Varroa destructor is a key contributor to honey bee (Apis mellifera L.) colony losses that threaten global economies. Some colonies, especially those displaying high levels of hygiene behaviour targeted towards $V$. destructor -infested cells, survive mite infestation. Worker bees displaying varroa sensitive hygiene (VSH) open infested brood cells and remove the contents, thereby suppressing mite reproduction. This study identifies features that distinguish cells uncapped by bees performing VSH from infested cells that VSH bees ignore. Brood cells targeted and uncapped by VSH bees were found to be more likely to contain multiple foundress females than nontargeted cells. They also contained higher numbers of mite offspring, and lay within brood cell patches that were more highly infested with $V$. destructor than were the surrounds of infested cells ignored by VSH bees. This study is the first to identify cell surrounds as a potential source of signals influencing the behaviour of bees performing VSH.
\end{abstract}

\section{Apis mellifera / Varroa destructor / social immunity}

\section{INTRODUCTION}

The contribution honey bees (Apis mellifera L.) make to the commercial pollination of agricultural crops and fruit places them amongst the most important of our productive livestock (Burgett et al. 2004; Klein et al. 2007). Evidence worldwide of declining honey bee health is therefore of significant concern (Delaplane and Mayer 2000; Morse and Calderone 2000; Gallai et al. 2009; Genersch and Aubert 2010; Nazzi et al. 2012). A recent causal analysis by Staveley et al. (2014) ranks the parasitic mite, Varroa destructor (Anderson and Trueman 2000), and its associated viruses as major contributors to colony losses,

Corresponding author: S. KIM, kimseohyun01@gmail.com

Manuscript editor : Peter Rosenkranz echoing earlier reports that $V$. destructor is a key factor explaining decreased survival in honey bees (Genersch 2010; Le Conte et al. 2010; Neumann and Carreck 2010; Rosenkranz et al. 2010). $V$. destructor reproduces in cells that house developing bees (brood cells) and feeds on the haemolymph of immature and adult bees (Donzé and Guerin 1994; Martin 1994; Oldroyd 1999; Webster and Delaplane 2001), vectoring viruses to honey bees as it does so (Donzé and Guerin 1994; Martin 1994; Bowen-Walker et al. 1999; Chen et al. 2006).

One of the main mechanisms that enables honey bees to survive the destructive effects of this mite is varroa sensitive hygiene (VSH). This social behaviour is performed by worker bees that detect and remove $V$. destructor-infested (pre-) pupae from capped brood cells (Harbo and Harris 2005). VSH reduces the reproductive potential of mites, slowing mite population growth and limiting the spread of infestation (Peng et al. 
1987; Harbo and Harris 2005; Ibrahim and Spivak 2006). As VSH has the potential to reduce the colony workforce, the selection of brood for removal must be accurate and targeted only to bees severely impacted by infestation. Evidence suggests that recognition of infested or healthy brood within a colony is enabled by chemical stimuli (Le Conte et al. 1989; Gramacho and Spivak 2003; Nazzi et al. 2004a; Le Conte et al. 2011; Schöning et al. 2012; Mondet et al. 2015; Mondet et al. 2016); but despite extensive effort, the nature and origin of cues used by honey bees to determine whether a (pre-) pupal bee within a waxcapped cell is to be removed remain unclear. Evidence points to the importance of the presence of $V$. destructor families (adult females and their offspring, Figure 1), as VSH bees remove (pre-) pupae from cells containing mite families more often than from singly infested cells (Boecking and Drescher 1994; Spivak 1996). In a recent study, we showed that total $V$. destructor numbers in cells uncapped by VSH bees were higher than in cells containing infested brood of the same age that were ignored by VSH bees (Mondet et al. 2016). This finding indicates that VSH is associated with the number of mites per brood cell (cells most likely to spread more $V$. destructor ) and the reproductive success of female mites (Boecking and Drescher 1992; Harbo and Harris 2005; Harbo and Harris 2009; Schöning et al. 2012).

Here we examine further the contents of miteinfested cells uncapped, or not, by bees performing VSH. The aim of this study is to identify features that differentiate $V$. destructorinfested cells targeted by VSH bees from infested cells that VSH bees ignore. We also investigate the contents of cell surrounds to determine whether signals that promote VSH behaviour might originate not only from VSH-targeted cells themselves, but also from cells in their immediate surroundings.

\section{MATERIALS AND METHODS}

\subsection{Identification of VSH-targeted and non-targeted cells}

The method used in this study to identify brood cells targeted by bees performing VSH has been described in detail elsewhere (Mondet et al. 2016), and is outlined in Figure 2. Briefly, frames of capped brood from colonies infested with $V$. destructor (donor colonies) were transferred into colonies exhibiting strong varroa sensitive hygiene behaviour (VSH colonies). There were three donor colonies and two VSH colonies used in this experiment. The VSH colonies were sourced from BettaBees Limited, New Zealand. Mite-infested brood frames from the donor colonies were inspected hourly for the appearance of brood cells that had been uncapped by VSH bees. We refer to these cells as VSH-targeted (TA) cells (Figure 2). If mite infestation of TA cells could not be confirmed, the cells were not included in the analysis. Cells containing dead brood were also excluded from the analysis to avoid confusion between cues related to dead brood and cues related to V. destructor infestation.

The contents of TA cells were collected as soon as the cells were identified and observations continued over a period of 2 days. After 2 days of sampling, the mite-infested brood frames were transferred to the laboratory. For each TA cell sampled, a mite-infested cell nearby that had been ignored by VSH bees over the 2-day observation period was selected for comparison with the VSHtargeted cell. These non-targeted (NT) cells were chosen randomly, but efforts were taken to stage-
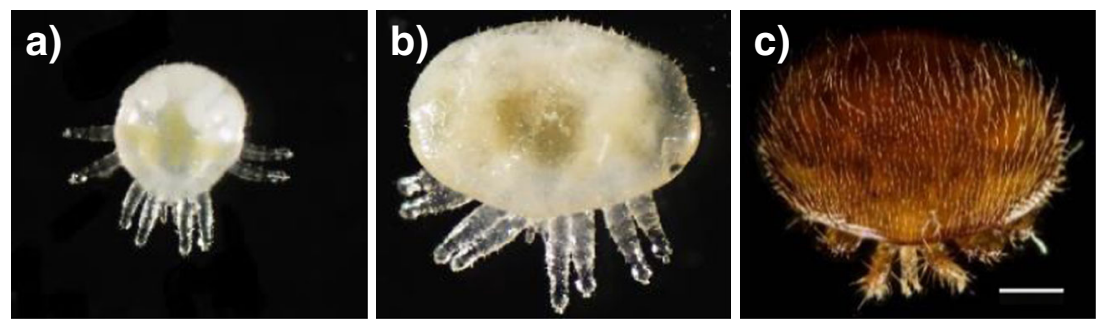

Figure 1. V. destructor mite categories. a Protonymph. b Deutonymph. c Adult female. Scale bar $=500 \mu \mathrm{m}$. 


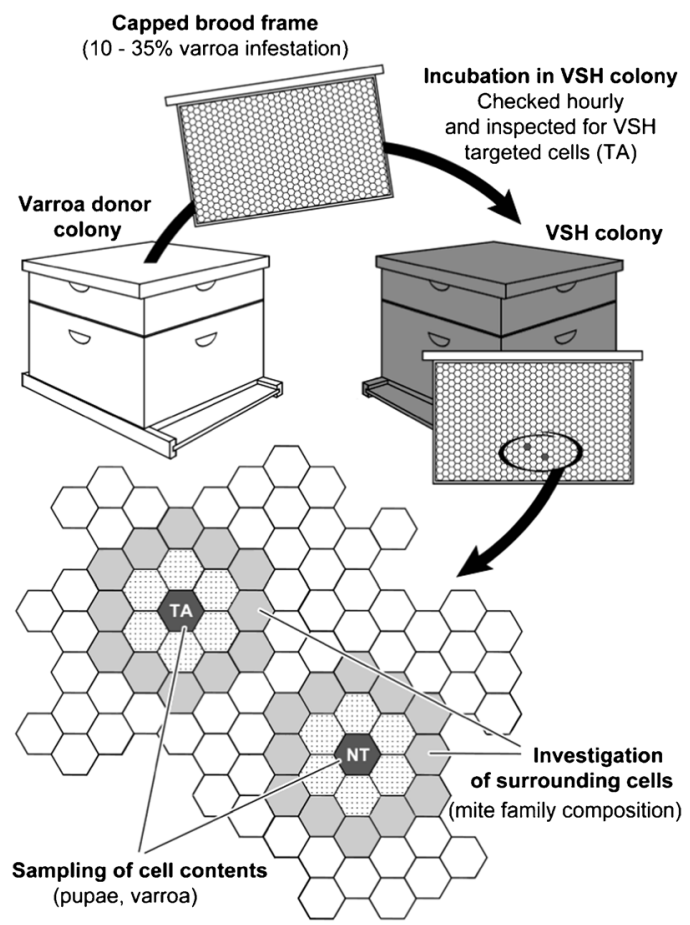

Figure 2. Identification of $V$. destructor-infested cells targeted by VSH bees (TA) and cells infested with mites but not targeted by VSH bees (NT). One NT cell was chosen randomly in the proximity of each identified TA cell and (pre-) pupae contained in the cells were matched for age. Inner rings of surrounding cells are highlighted in light grey and outer rings in dark grey.

match the (pre-) pupae of TA and NT cells. NT cells were sampled to reveal differences between infested cells that were targeted (TA cells) and infested cells that remained capped (NT cells) during the incubation period. For every cell examined, the developmental stage of the (pre-) pupae was recorded, as well as the composition of the mite family in each cell (see below).

\subsection{Sampling of surrounding cells}

In addition to the contents of TA cells and NT cells, two layers of cells surrounding each TA and NT cell were opened and the contents examined. The layer of cells immediately adjacent to the TA or NT cell is referred to here as the inner ring, whereas the layer of cells surrounding the inner ring is referred to as the outer ring (Figure 2).

\subsection{Mite family composition}

For each cell examined, information was recorded about the developmental stage of the bee, as well as the number and developmental stage(s) of mites present in the cell. No attempt was made in this study to determine the gender of developing mites. Juvenile mites were categorised as either protonymphs or deutonymphs, based on shape and size (Figure 1). Indeed, in early stages of development, female and male mites are not easy to distinguish. Adult females on the other hand are easily recognised due to the colouration of the cuticle. Numbers of $V$. destructor belonging to each of four categories (adult females, eggs, protonymphs, and deutonymphs) were recorded for each TA or NT cell, and for all cells in the inner and outer rings of surrounding cells.

\subsection{Statistical analysis}

All statistical analyses were conducted using CRAN R version 3.3.2 (2017) for windows (Auckland, New Zealand). Wald tests based on generalised linear mixed models (GLMM) were used to analyse differences between TA and NT cells, as well as between the surrounds of these cells, except for analysis of proportion of TA and NT cells containing offspring (chi-squared test) and numbers of $V$. destructor offspring and numbers of foundress females per surrounding cell (linear mixed models, LMM). To take into consideration the fact that sampled cells originate from the same donor or VSH colony, both variables were included as fixed factors in all models (with donor colony nested into VSH colony). Sample ID was also consistently included as a random factor. Prevalence data were analysed using binomial distribution (link: logit) whereas count data were analysed using Poisson or negative binomial distribution (link: $\log$ ).

\section{RESULTS}

\subsection{Numbers of $V$. destructor in targeted and non-targeted cells}

VSH-targeted (TA) cells contained significantly higher numbers of foundress females per cell 
than cells that were not targeted by VSH bees (Figure $3 \mathrm{a}, \chi^{2}=10.97, p<0.001$ ). Sample size is 42 for both sample types. The proportions of TA and NT cells containing $V$. destructor offspring were similar (Figure $3 b, \chi^{2}=0.014, \mathrm{df}=1, p=$ 0.91). However, numbers of $V$. destructor offspring per cell were found to be higher in TA cells than in NT cells (Fig 3c, $\chi^{2}=37495.6, p<0.001$ ). Closer examination of the mite offspring revealed no differences in the numbers of $V$. destructor eggs present in each cell type (Figure $3 \mathrm{~d} \chi^{2}=$ $1.36, p=0.24$ ), but TA cells contained significantly higher numbers of protonymphs (Figure 3e, $\chi^{2}=11.080, p<0.001$ ) and deutonymphs (Figure 3f, $\chi^{2}=9.81, p=0.0017$ ) per cell than NT cells.

\subsection{Contents of cells surrounding targeted and non-targeted cells}

To examine the surrounds of TA and NT cells, we began by examining the proportion of surrounding cells that contained brood. Overall, 738 cells were examined for each cell type. The surrounds of TA and NT cells are similar in terms of brood content (Figure $4 \mathrm{a}, \chi^{2}=2.18, p=0.14$ ). In sharp contrast, a significantly higher proportion of cells surrounding targeted cells contained $V$. destructor than cells surrounding NT cells (Figure $4 \mathrm{~b}, \chi^{2}=22.25, p<0.001$ ). This was true also, if empty cells were discounted and only cells containing brood were included in the analysis (Figure $4 \mathrm{c}, \chi^{2}=17.67, p<0.001$ ). Unlike the results for TA versus NT cells (Figure 3 ), there were no significant differences in the numbers of foundress females per cell between the surrounding cells of TA and NT cells (Figure $4 \mathrm{~d}, \chi^{2}=0.32, p=$ $0.57)$. There was also no significant difference between the surrounds of TA and NT cells in the proportions of cells with offspring (Figure $4 \mathrm{e}, \chi^{2}=$ $0.65, p=0.42$ ) or in the numbers of $V$. destructor offspring per cell (Figure 4f, $\chi^{2}=0.44, p=0.51$ ).

\subsection{Comparison of inner and outer rings}

Further analysis revealed significant differences between the inner and outer rings of surrounding cells (Table I). The proportion of cells infested with $V$. destructor was significantly higher in the inner rings of TA cells than in the outer rings of this cell type (Figure 5a). Moreover, the outer rings of TA cells displayed a significantly higher proportion of mite-infested cells than did the outer rings of NT cells (Figure 5a). Such patterns could potentially reflect differences in proportions of cells containing brood (Figure 5b). However, analyses of broodcontaining cells alone confirms that the proportion of brood-containing cells infested with $V$. destructor was highest in the inner rings of TA cells, and significantly higher in the inner rings than in the outer rings of this cell type (Figure 5c). This analysis revealed also that both, the inner and outer rings of TA cells had a higher proportion of $V$. destructor-infested brood cells than the rings surrounding NT cells (Figure 5c). Despite these differences, the numbers of foundress females present in infested cells (Figure 5d), the proportion of cells with $V$. destructor offspring (Figure 5e), and numbers of $V$. destructor offspring per infested cell (Figure $5 \mathrm{f}$ ) in the inner and outer rings of TA and NT cells were similar (Table I).

\section{DISCUSSION}

In this study, brood cells uncapped by bees performing VSH exhibited three characteristic features that distinguished them from the V. destructor-infested cells that VSH bees ignored; they contained multiple mature females, higher numbers of mite offspring, and they were surrounded by cells with higher levels of mite infestation than the cell surrounds of nontargeted cells. These results confirm the strong link that has been identified between high mite numbers and VSH behaviour (Boecking and Drescher 1994; Spivak 1996; Harbo and Harris 2005; Harbo and Harris 2009; Mondet et al. 2016), and they are the first to identify cell surrounds as a potential source of signals capable of influencing the selective targeting of mite-infested brood by worker bees performing VSH.

A foundress female mite that enters a worker brood cell will lay up to five eggs (Donzé and Guerin 1994; Martin 1994). In the present study, $V$. destructor-infested cells ignored by bees performing VSH seldom exhibited total numbers 


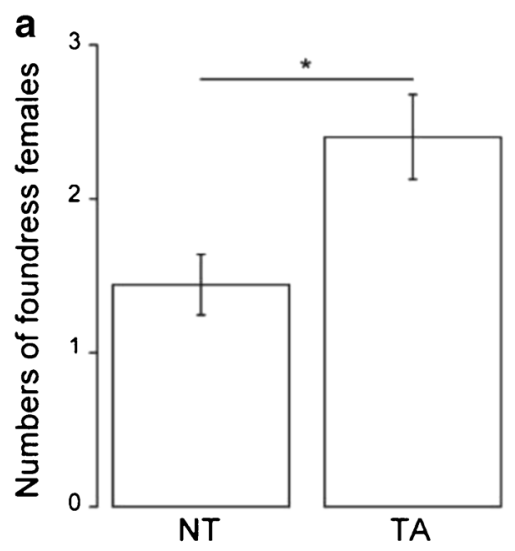

b
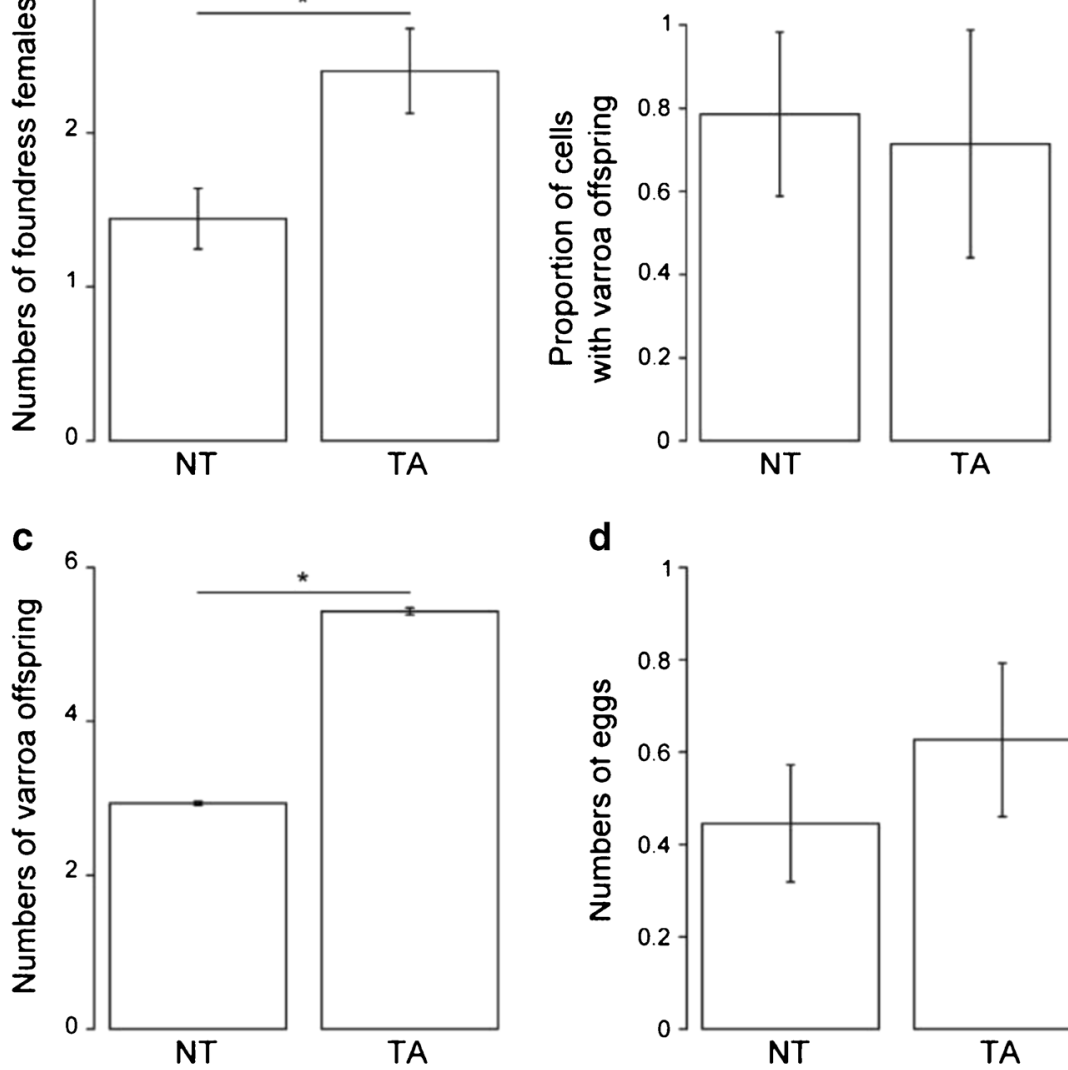

d
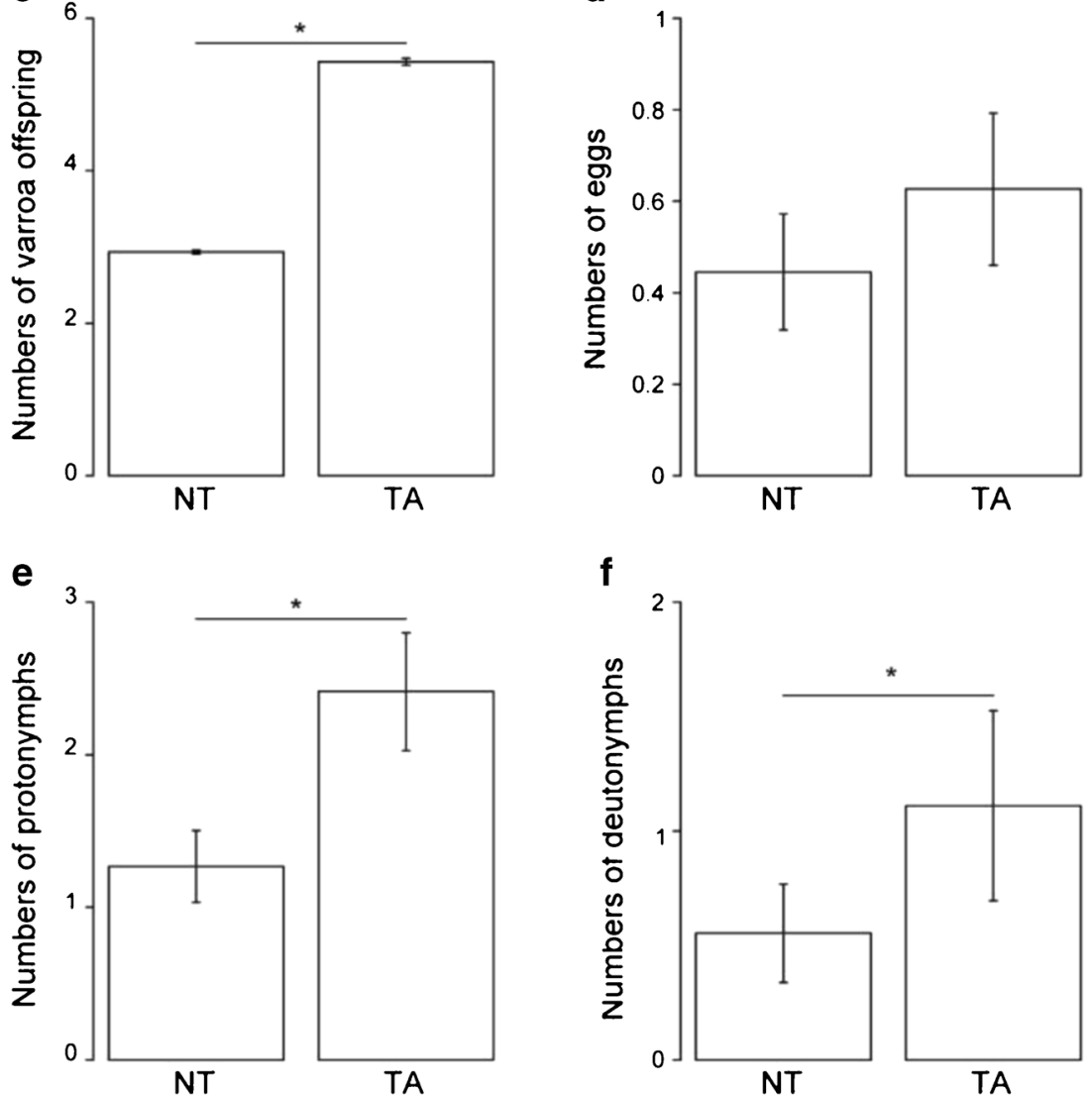

Figure 3. Comparison of contents in NT and TA cells $\left(n=\mathrm{NT}_{42}, \mathrm{TA}_{42}\right)$. a Number of foundress females. $\mathbf{b}$ Proportion of cells with offspring. c Total numbers of offspring in cells containing developing V. destructor. Overall, 33 of 42 NT cells contained $V$. destructor offspring while 30 out of 42 TA cells contained $V$. destructor offspring. (d-f respectively) Numbers of $V$. destructor eggs, protonymphs and deutonymphs in cells containing developing mites. Back-transformed LSMeans $( \pm$ s.e.m. $)$ are shown throughout. Significant differences $(p<0.05)$ are indicated with asterisks. 


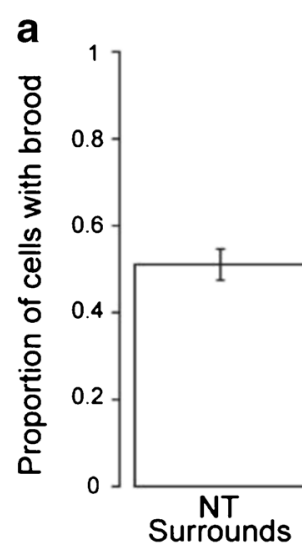

C

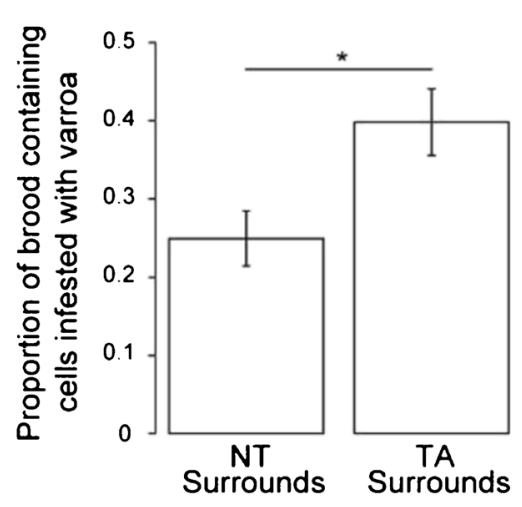

e

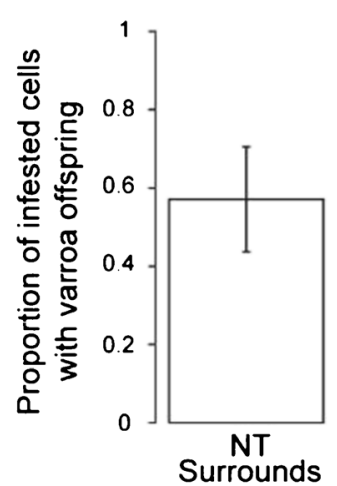

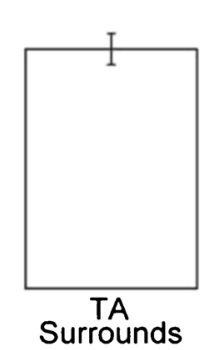

Surrounds

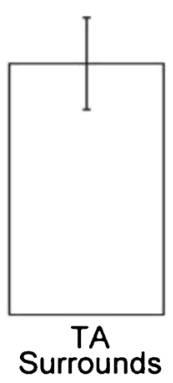

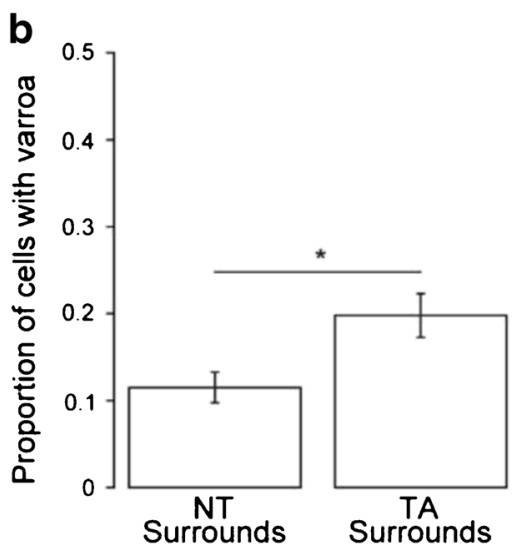
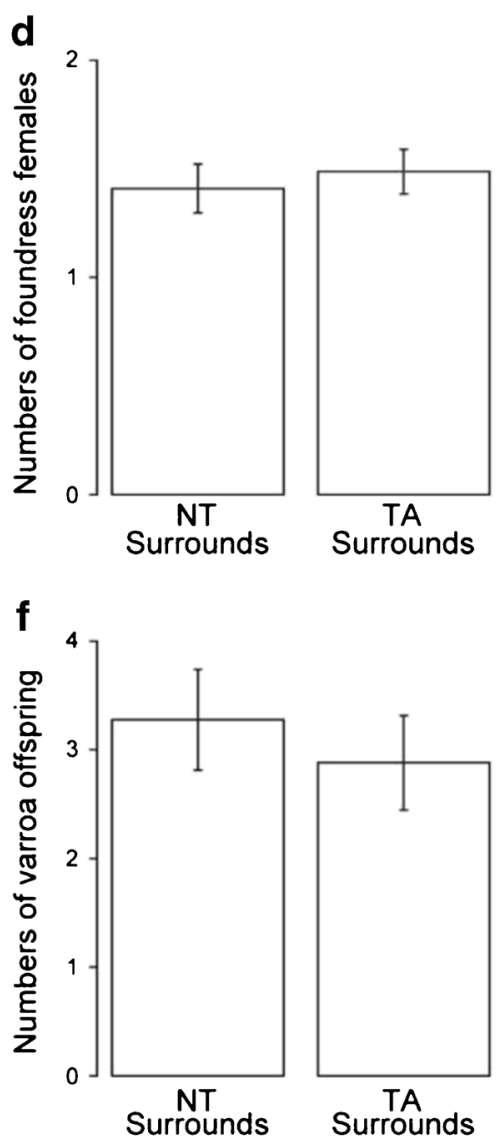

Figure 4. Comparisons of contents in cell surrounds $\left(\mathrm{n}=\mathrm{NT}_{41}, \mathrm{TA}_{41}\right)$. a Proportion of surrounding cells with brood. b Proportion of surrounding cells infested with $V$. destructor. c Proportion of brood-containing cells infested with $V$. destructor. d Numbers of foundress female V. destructor in infested cells. e Proportion of mite-infested cells containing offspring. f Numbers of $V$. destructor offspring in cells containing developing mites. Back-transformed LSMeans $( \pm$ s.e.m.) are shown throughout. Significant differences $(p<0.05)$ are indicated with asterisks. 
Table I.. Comparison of contents in inner and outer rings ( $n$ values: NT=41, TA=41). Significant differences $(p<0.05)$ are highlighted in bold.

\begin{tabular}{|c|c|c|c|c|c|c|}
\hline \multirow[t]{3}{*}{ Test } & \multirow{2}{*}{\multicolumn{2}{|c|}{$\begin{array}{l}\text { Sample type } \\
\text { (NT, TA) }\end{array}$}} & \multicolumn{4}{|l|}{ Ring level } \\
\hline & & & \multicolumn{2}{|c|}{ (Inner, Outer) } & \multicolumn{2}{|c|}{ Interaction } \\
\hline & $\chi^{2}(\mathrm{df}=1)$ & $P$ & $\chi^{2}(\mathrm{df}=1)$ & $P$ & $\chi^{2}(\mathrm{df}=1)$ & $P$ \\
\hline Proportion of cells with $V$. destructor & 22.022 & $<0.001$ & 9.56 & 0.0020 & 3.37 & 0.067 \\
\hline Proportion of cells with brood & 2.20 & 0.14 & 14.56 & $<0.001$ & 0.71 & 0.40 \\
\hline Proportion of infested brood-containing cells & 17.26 & $<0.001$ & 1.65 & 0.20 & 3.096 & 0.078 \\
\hline Numbers of foundress females & 1.35 & 0.25 & 0.10 & 0.75 & 0 & 1 \\
\hline Proportion of cells with $V$. destructor offspring & 0.61 & 0.44 & 0.055 & 0.81 & 1.34 & 0.25 \\
\hline Numbers of offspring & 9.96 & 0.63 & 9.045 & 0.19 & 5.39 & 0.21 \\
\hline
\end{tabular}

of $V$. destructor offspring that exceeded this number. Total numbers of $V$. destructor offspring in VSH-targeted cells, on the other hand, were significantly higher than in NT cells, a finding consistent with the higher numbers of mature female mites identified in VSH-targeted cells. Young female mites generally undergo their final moult to become adults as the developing bee that occupies the brood cell reaches the final stages of metamorphic adult development (Rosenkranz et al. 2010). As no final moult exuviae were identified in VSHtargeted cells, and all brood identified in cells uncapped by VSH bees were at pupal stage 7 or younger, we assume that all the adult female mites identified in this study were foundress females. Levels of mite infestation in the brood frames used in this study were high. Approximately $25 \%$ infestation was recorded in cells surrounding NT cells and $40 \%$ infestation in the surrounds of TA cells, conditions that may have enhanced the likelihood of finding multiple foundress females in same cell. Cells with multiple foundress females and very high offspring numbers were targeted selectively by VSH bees, indicating that such cells are clearly distinguishable from the cells in their immediate surrounds. The explanation suggested by the results of this study is that mite numbers in the cell surrounds were lower than in targeted cells.

It is important to note in this study that the proportions of TA and NT cells with mite offspring were similar, a finding consistent with earlier studies showing that the mere presence of offspring is not sufficient to trigger the removal of infested (pre)pupae by VSH bees (Harris et al. 2010). Indeed, the presence of $V$. destructor offspring appears to be less important than the actual numbers of offspring in each cell. While it remains unclear whether $V$. destructor themselves produce signals that can be detected by VSH bees (Rosenkranz et al. 1993; Harris 2007; Harris et al. 2010), evidence that honey bees detect and display hygiene behaviour towards mite-parasitized brood is compelling (Peng et al. 1987; Boecking and Drescher 1992; Rosenkranz et al. 1993; Spivak 1996; Harbo and Harris 2005; Ibrahim and Spivak 2006; Harris et al. 2010). V. destructor infestation has wide-ranging impacts on the health and physiology of developing bees (Schneider and Drescher 1987; Bowen-Walker and Gunn 2001; Amdam et al. 2004; Yang and Cox-Foster 2007; Annoscia et al. 2012), and a growing body of evidence suggests that chemical cues originating from $V$. destructor-infested brood enable VSH bees to identify which brood to sacrifice (Spivak et al. 2003; Nazzi et al. 2004b; Schöning et al. 2012; Mondet et al. 2016). The observation that worker bees do not respond to newly infested cells (Harris 2007) suggests that intensification of chemical signals to a level detectable by VSH bees takes time. Gradual increases in the numbers of mite offspring feeding on the haemolymph of a developing bee, and progressive effects of diseases caused by viral vectoring are likely to contribute to the generation of signals detectable by VSH bees. The time dependence of these processes might explain why foundress 

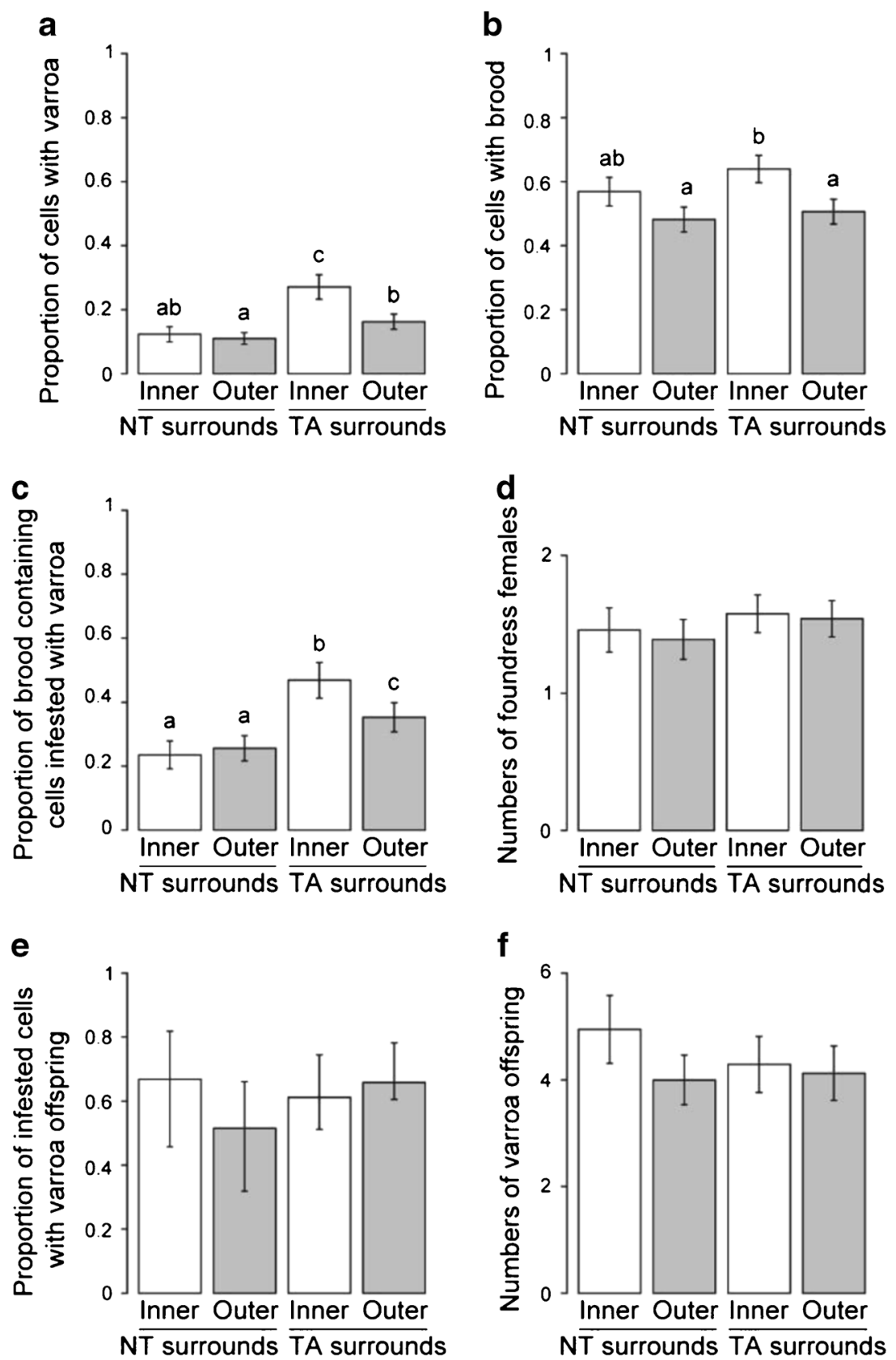

Figure 5. Comparison of contents in inner and outer rings. a Proportion of surrounding cells with $V$. destructor. b Proportion of surrounding cells with brood. c Proportion of brood-containing cells with $V$. destructor. d Numbers of foundress female $V$. destructor in infested cells. e Proportion of mite-infested cells with offspring. $\mathbf{f}$ Numbers of $V$. destructor offspring in cells containing developing mites. Inner rings of surrounding cells are shown in white and outer rings in grey. Back-transformed LSMeans ( \pm s.e.m.) are systematically shown throughout. Different letters above bars indicate significant differences $(p<0.05)$ between groups. 
female mites lay all or most of their offspring before brood are targeted for removal by VSH bees.

Signal intensification could potentially result also from increases in the density of $V$. destructor-infested cells. This is particularly relevant in this study, because our results reveal for the first time that VSH-targeted cells are surrounded by a significantly higher density of $V$. destructor-infested cells than are infested cells ignored by VSH bees. In other words, the most mite-compromised bees are located within patches of brood characterised by high levels of mite infestation. How such patches arise has yet to be determined, but our study suggests that signals arising from these highly infested patches have the potential to guide VSH bees to areas in which they will find the most mite-compromised brood. Patch recognition could provide an additional mechanism to ensure that VSH is an effective and efficient behavioural strategy in which only brood most affected by parasitism are removed from the colony (Mondet et al. 2016; Page et al. 2016).

\section{ACKNOWLEDGEMENTS}

We would like to thank Kim Garrett, Murray McKenzie and Frans Laas for their technical assistance, and BettaBees Research limited for providing honey bee colonies for this study. This research was funded by grants to SHK and ARM from the Department of Zoology, University of Otago.

\section{AUTHORS' CONTRIBUTIONS}

SHK, FM and AM conceptualised and designed experiments; SHK performed the experiments with assistance from FM; MH participated in the analysis of the data; AM supervised the research; SHK drafted the article and all authors participated in the revisions of the manuscript. All authors have read and approved the final manuscript.

\section{COMPLIANCE WITH ETHICAL STANDARDS}

Conflict of interest The authors declare that they have no potential conflict of interest in relation to the study in this paper.

General summaryVarroa destructor are ectoparasitic mites that are key contributors to honey bee (Apis mellifera
L.) colony losses that threaten global economies and ecosystems worldwide. Worker bees performing varroa sensitive hygiene (VSH) interfere with mite reproduction by opening infested brood cells and removing the cell contents. This study identifies distinguishing features of miteinfested brood cells uncapped by honey bees performing $\mathrm{VSH}$ and provides insights into the origin of signals that trigger this remarkable behaviour. Infested brood cells that were uncapped by VSH bees and those that were infested but ignored by VSH bees were sampled for $V$. destructor contents (Figures 1 and 2). We found that brood cells targeted by VSH bees contain more foundress females and offspring compared to non-targeted cells (Figure 3). Targeted cells also lay within brood cell patches that were more highly infested with $V$. destructor than were the surrounds of non-targeted brood cells (Figure 4). Furthermore, it was revealed that mite infestation rates were particularly high in cells immediately adjacent to targeted cells, suggesting that signals arising from these cells may influence the targeting of brood for removal from the colony (Figure 5 and Table I). We propose that patches of brood heavily infested with mites attract the attention of VSH bees, drawing them to areas that house the most severely mite-compromised brood.

Les abeilles avec un comportement hygiénique sensible au varroa éliminent les abeilles les plus compromises par l'acarien des plaques très infestées du couvain.

Apis mellifera / Varroa destructor/ immunité sociale.

Honigbienen mit "Varroa-sensitive-Hygiene" entfernen die meisten mit Milben infizierten Brutstadien aus stark befallenen Brutarealen (Patches).

Apis mellifera / Varroa destructor / soziale Immunität.

\section{REFERENCES}

Amdam, G., Hartfelder, K., Norberg, K., Hagen, A., Omholt, S. (2004) Altered physiology in worker honey bees (Hymenoptera: Apidae) infested with the mite Varroa destructor (Acari: Varroidae): A factor in colony loss during overwintering. J. Econ. Entomol. 97, 741-747

Anderson, D., Trueman, J. (2000) Varroa jacobsoni (Acari: Varroidae) is more than one species. Exp. Appl. Acarol. 24, 165-189

Annoscia, D., del Piccolo, F., Nazzi, F. (2012) How does the mite Varroa destructor kill the honeybee Apis mellifera? Alteration of cuticular hydrcarbons and water loss in infested honeybees. J. Insect Physiol. 58, $1548-1555$

Boecking, O., Drescher, W. (1992) The removal response of Apis mellifera L. colonies to brood in wax and 
plastic cells after artificial and natural infestation with Varroa jacobsoni Oud. and to freeze-killed brood. Exp. Appl. Acarol. 16, 321-329

Boecking, O., Drescher, W. (1994) Rating of signals which trigger Apis mellifera L. bees to remove mite-infested brood. Apidologie. 25, 459-461

Bowen-Walker, P., Gunn, A. (2001) The effect of the ectoparasitic mite, Varroa destructor, on adult worker honeybee (Apis mellifera) emergence weights, water, protein, carbohydrate and lipid levels. Exp. Appl. Acarol. 101, 207-217

Bowen-Walker, P., Martin, S., Gunn, A. (1999) The transmission of deformed wing virus between honeybees (Apis mellifera L.) by the ectoparasitic mite Varroa jacobsoni Oud. J. Invertebr. Pathol. 73 , 101-106

Burgett, M., Rucker, R., Thurman, W. (2004) Economics and honey bee pollination markets. Am. Bee J. 144, 269-271

Chen, Y., Evans, J., Feldlaufer, M. (2006) Horizontal and vertical transmission of viruses in the honeybee, Apis mellifera. J. Invertebr. Pathol. 92 , 152-159

Delaplane, K., Mayer, D. (2000) Crop Pollination by Bees. CABI Publishing, New York.

Donzé, G., Guerin, P. (1994) Behavioral attributes and parental care of Varroa mites parasitizing honeybee brood. Behav. Ecol. Sociobiol. 34, 305-319

Gallai, N., Salles, J., Settele, J., Vaissière, B. (2009) Economic valuation of the vulnerability of world agriculture confronted with pollinator decline. Ecol. Econ. 68, 810-821

Genersch, E. (2010) Honey bee pathology: Current threats to honey bees and beekeeping. Appl Microbiol Biotechnol. 87, 87-97

Genersch, E., Aubert, M. (2010) Emerging and reemerging viruses of the honey bee (Apis mellifera L.). Vet. Res. 41, 54-74

Gramacho, K., Spivak, M. (2003) Differences in olfactory sensitivity and behavioral responses among honey bees bred for hygienic behavior. Behav. Ecol. Sociobiol. 54, 472-479

Harbo, J., Harris, J. (2005) Suppressed mite reproduction explained by the behaviour of adult bees. J. Apic. Res. 44, 21-23

Harbo, J., Harris, J. (2009) Responses to varroa by honey bees with different levels of varroa sensitive hygiene. Bee World. 48, 156-161

Harris, J. (2007) Bees with varroa sensitive hygiene preferentially remove mite infested pupae aged $\leq$ five days post capping. J. Apic. Res. 46, 134-139

Harris, J., Danka, R., Villa, J. (2010) Honey bees (Hymenoptera: Apidae) with the trait of Varroa sensitive hygiene remove brood with all reproductive stages of Varroa mites (Mesostigmata: Varroidae). Ann. Entomol. Soc. Am. 103, 146-152

Ibrahim, A., Spivak, M. (2006) The relationship between hygienic behavior and suppression of mite reproduction as honey bee (Apis mellifera) mechanisms of resistance to Varroa destructor. Apidologie 37, 31-40
Klein, A., Vaissiere, B., Cane, J., Steffan-Dewenter, I., Cunningham, S., et al. (2007) Importance of pollinators in changing landscapes for world crops. Proceedings of the Royal Society B: Biological Sciences. 274, 303-313

Le Conte, Y., Arnold, G., Trouiller, J., Masson, C., Chappe, B., et al. (1989) Attraction of the parasitic mite varroa to the drone larvae of honey bees by simple aliphatic esters. Science 245, 638-639

Le Conte, Y., Ellis, M., Ritter, W. (2010) Varroa mites and honey bee health: Can varroa explain part of the colony losses? Apidologie. 41, 353-363

Le Conte, Y., Alaux, C., Martin, J., Harbo, J., Harris, J., et al. (2011) Social immunity in honeybees (Apis mellifera ): Transcriptome analysis of varroa-hygienic behaviour. Insect Mol. Biol. 20 (3), 399-408

Martin, S. (1994) Ontogenesis of the mite Varroa jacobsoni Oud. in worker brood of the honeybee Apis mellifera L. under natural conditions. Exp. Appl. Acarol. 18, 87-100

Mondet, F., Alaux, C., Severac, M., Rohmer, M., Mercer, A., et al. (2015) Antennae hold a key to Varroasensitive hygiene behaviour in honey bees. Sci. Rep. 5, 10454

Mondet, F., Kim, S., de Miranda, J., Beslay, D., Le Conte, Y., et al. (2016) Specific cues associated with honey bee social defence against Varroa destructor infested brood. Sci. Rep. 6, 25444

Morse, R., Calderone, N. (2000) The value of honey bee pollination in the United States. Bee Culture. 128, 1-15

Nazzi, F., Vedova, G., D'agaro, M. (2004a) A semichemical from brood cells infested by Varroa destructor triggers hygienic behaviour in Apis mellifera . Apidologie. 35, 65-70

Nazzi, F., Milani, N., Della Vedova, G. (2004b) A semiochemical from larval food influences the entrance of Varroa destructor into brood cells. Apidologie. 35, 403-410

Nazzi, F., Brown, S., Annoscia, D., del Piccolo, F., di Prisco, G., et al. (2012) Synergistic parasite-pathogen interactions mediated by host immunity can drive the collapse of honeybee colonies. PLoS Path. 8, 1-16

Neumann, P., Carreck, N. (2010) Honey bee colony losses. J. Apic. Res. 49, 1-6

Oldroyd, B. (1999) Coevolution while you wait: Varroa jacobsoni, a new parasite of western honeybees. Trends Ecol. Evol. 14, 312-315

Page, P., Lin, Z., Buawangpong, N., Zheng, H., Hu, F., et al. (2016) Social apoptosis in honey bee superorganisms. Sci. Rep. 6, 27210

Peng, Y., Fang, Y., Xu, S., Ge, L. (1987) The resistance mechanism of the Asian honey bee Apis cerana Fabr. to an ectoparasitic mite, Varroa jacobsoni Oudemans. J. Invertebr. Pathol. 49, 54-60

Rosenkranz, P., Tewarson, N., Singh, A., Engels, W. (1993) Differential hygienic behaviour towards Varroa jacobsoni in capped worker brood of Apis cerana depends on alien scent adhering to the mites. J. Apic. Res. 32, 89-93 
Rosenkranz, P., Aumeier, P., Ziegelmann, B. (2010) Biology and control of Varroa destructor. J. Invertebr. Pathol. 103, 96-119

Schneider, P., Drescher, W. (1987) The influence of Varroa jacobsoni Oud. on weight; development on weight and hypopharyngeal glands; and longevity of Apis mellifera L. . Apidologie. 18, 101-110

Schöning, C., Gisder, S., Geiselhardt, S., Kretschmann, I., Bienefeld, K., et al. (2012) Evidence for damagedependent hygienic behaviour towards Varroa destructor parasitized brood in the western honey bee, Apis mellifera . J. Exp. Biol. 215, 264-271

Spivak, M. (1996) Honey bee hygienic behavior and defense against Varroa jacobsoni . Apidologie. 27, 245-260
Spivak, M., Masterman, R., Ross, R., Mesce, K. (2003) Hygienic behavior in the honey bee (Apis mellifera L.) and the modulatory role of octopamine. J. Neurobiol. $\mathbf{5 5}, 341-354$

Staveley, J., Law, S., Fairbrother, A., Menzie, C. (2014) A causal analysis of observed declines in managed honey bees (Apis mellifera). Human and Ecological Risk Assessment: An International Journal. 20, 566-591

Webster, T., Delaplane, K. (2001) Mites of the Honey Bee. Dadant and Sons Inc, Illinois.

Yang, X., Cox-Foster, D. (2007) Effects of parasitization by Varroa destructor on survivorship and physiological traits of Apis mellifera in correlation with viral incidence and microbial challenge. Parasitology. 134, 405-412 